\title{
Perbandingan Film Antosianin Beras Merah Dan Kedelai Hitam Sebagai Kandidat Indikator Kualitas Susu Cair
}

\author{
Comparison Of Anthocyanin Films Of Red Rice And Black Soybean As A Candidate Indicator \\ Of The Quality Of Liquid Milk
}

\author{
Fita Widiyatun ${ }^{\mathrm{a}^{*}}$, Neng Nenden Mulyaningsih ${ }^{\mathrm{b}}$, Sudirman $^{\mathrm{b}}$ \\ ${ }^{a}$ Program Studi Teknik Informatika FTMIPA Universitas Indraprasta PGRI \\ Jl. Nangka No.58C Tanjung Barat Jagakarsa, Jakarta Selatan 12530 \\ ${ }^{b}$ Program Studi Pendidikan Fisika FTMIPA Universitas Indraprasta PGRI \\ Jl. Nangka No.58C Tanjung Barat Jagakarsa, Jakarta Selatan 12530 \\ *Surel: fita.wdy@gmail.com
}

\section{INFO ARTIKEL}

Diterima 10 Januari 2019

Direvisi 1 April 2019

Disetujui 21 Mei 2019

Nomor Artikel 201905

Halaman 27-31

\section{Kata kunci:}

Susu cair

Antosianin

Beras merah

Kedelai hitam

TGA
Abstract

Fresh milk is a drink commonly consumed by people in Indonesia, both young and old. Milk contains essential nutrients such as vitamins, proteins, calcium, magnesium, phosphorus and zinc. However, milk is also a good medium for microbial growth. Therefor required a tool to know the quality of liquid milk. This research was conducted on the characterization and analysis of the relationships with film of red rice and black soybeans. The relationships with the film created by adding a mixture of chitosan with polyvinyl alcohol and comparison 3:7 as much as $75 \mathrm{ml}$ into the relationships with brown rice and black soybeans each of as many as 25 $\mathrm{ml}$. The films were characterized with the thermal gravimetric analysis (TGA) on atmospheric oxygen. The results show that black soybeans have more criteria allows as a candidate indicator of quality fresh milk compared with brown rice.

Keywords:liquid milk, anthocyanin, brown rice, black soybeans, TGA

\begin{abstract}
Abstrak
Susu cair merupakan minuman yang umum dikonsumsi oleh masyarakat Indonesia, baik tua maupun muda. Susu mengandung nutrisi penting seperti vitamin, protein, kalsium, magnesium, fosfor dan zinc. Akan tetapi, susu juga merupakan media yang baik untuk pertumbuhan mikroba. Oleh karena itu diperlukan suatu alat untuk mengetahui kualitas susu cair. Pada penelitian ini dilakukan karakterisasi dan analisis terhadap film antosianin dari beras merah dan kedelai hitam. Film antosianin dibuat dengan menambahkan campuran chitosan dan polivinil alkohol dengan perbandingan 3:7 sebanyak $75 \mathrm{ml}$ ke dalam antosianin beras merah dan kedelai hitam masing-masing sebanyak $25 \mathrm{ml}$. Film yang dihasilkan dikarakterisasi dengan thermal gravimetric analysis (TGA) pada atmosfer oksigen. Hasilnya menunjukkan bahwa kedelai hitam memiliki kriteria yang lebih memungkinkan sebagai kandidat indikator kualitas susu cair dibandingkan dengan beras merah.
\end{abstract}




\section{PENDAHULUAN}

Susu merupakan salah satu minuman yang banyak dikonsumsi oleh masyarakat Indonesia. Susu cair tergolong dalam bahan pangan dengan kandungan air dan protein yang tinggi sehingga cocok untuk pertumbuhan mikroba atau sering juga disebut perishable food. Penyimpanan yang tidak tepat adalah salah satu faktor yang menyebabkan bahan pangan ini cepat ditumbuhi oleh mikroba sehingga perlu kejelian sebelum dikonsumsi. Penyimpanan pada suhu yang tepat dan kelengkapan informasi yang diberikan produsen kepada konsumen sangat berperan penting.

Beberapa dekade terakhir telah di ciptakan kemasan pintar yakni sistem pengemasan yang mampu memberikan fungsi intelligent yaitu pendeteksi, perekam, komunikasi dan perasa [1]. Salah satu konsep kemasan pintar yang banyak dikembangkan adalah adanya indikator kesegaran didalam kemasan. Indikator yang telah ada biasanya menggunakan pewarna sintetis seperti bromthymol blue (BTB), bromocresol green (BCG), bromocresol purple (BCP), dan methyl red (MR) [2].

Penggunaan pewarna sintetis pada indikator menimbulkan efek tidak baik bagi kesehatan jika indikator kontak dengan bahan pangan yang dikemas. Efek tidak baik dari penggunaan indikator dengan pewarna sintetis dapat dihindari dengan cara menggunakan pewarna alami pada indikator kesegaran seperti zat warna antosianin.

Antosianin merupakan salah satu pewarna alami karena merupakan zat berwarna merah, jingga, ungu, ataupun biru yang banyak terdapat pada bunga dan buah-buahan $[3,4]$. Antosianin merupakan senyawa flavonoid yang memiliki kemampuan sebagai antioksidan. Antosianin dalam bentuk aglikon lebih aktif daripada bentuk glikosidanya [5]. Zat pewarna alami antosianin tergolong ke dalam turunan benzopiran. Struktur utama turunan benzopiran ditandai dengan adanya cincin aromatik benzena $\left(\mathrm{C}_{6} \mathrm{H}_{6}\right)$ yang dihubungkan dengan tiga atom karbon yang membentuk cincin [6].

Warna dan stabilitas pigmen antosianin tergantung pada struktur molekul secara keseluruhan. Perubahan warna pada zat warna alami antosianin terbentuk dari pigmen sianidin dengan penambahan atau pengurangan gugus hidroksil, metilasi dan glikosilasi [7]. Semakin banyak substitusi gugus $\mathrm{OH}$ pada struktur antosianin dapat menyebabkan warna semakin biru, sedangkan metoksilasi akan menyebabkan warnanya semakin merah [8].

Sumber antosianin banyak jenisnya, bisa berasal dari biji-bijian, bunga-bungaan atau bisa juga dari umbi-umbian. Contoh bahan hayati lokal sumber antosianin yaitu mawar, kana merah, kayu secang, anggur hitam, ubi ungu, beras merah dan kedelai hitam. Beras merah dan kedelai hitam merupakan jenis bahan makanan yang sudah biasa dikonsumsi sehingga aman jika bersentuhan dengan makanan atau minuman lain saat digunakan sebagai indikator kualitas makanan atau minuman.

Beras merah tergolong dalam famili Gramineae, sub famili Oryzaidae, suku/genus dan spesies Oryza sativa[9]. Beras merah memiliki lapisan di luar endosperma yang disebut lapisan aleurone/gabah [10]. Kandungan antosianin pada beras merah terletak pada lapisan aleuronnya [11]. Kadar antosianin pada beras merah berkisar antara 0,33 - 1,39 mg/100 g [12].

Kedelai hitammerupakan salah satu varietas dari kedelai (Glycine max). Biji kedelai mengandung senyawa bioaktif yang mempunyai sifat antioksidatif. Kedelai mengandung senyawa-senyawa antioksidan diantaranya adalah vitamin $\mathrm{E}$, vitamin $\mathrm{A}$, provitamin $\mathrm{A}$, vitamin $\mathrm{C}$ dan senyawa flavonoid golongan isoflavon, genistein dan daidzein [13]. Kandungan antosianin pada kedelai hitam terdapat pada bagian kulitnya. Kadar antosiani kedelai hitam sekitar 5,78 $\mathrm{mg} / 100 \mathrm{~g}$ kedelai $[14,15]$.

Zat pewarna alami antosianin pada beras merah dan kedelai hitam dapat dimanfaatkan untuk membuat sensor yang sensitive terhadap kehadiran senyawa volatile amin sehingga dapat mendeteksi kualitas minuman susu cair. Oleh karena itu pada penelitian ini diamati Perbandingan Kadar Antosianin Beras Merah dan Kedelai Hitam Melalui karakterisasi dengan atomic absorption spectroscopy (AAS) dan thermogravimetric analysis (TGA).

\section{METODE PERCOBAAN}

Penelitian yang dilakukan meliputi 2 tahapan yaitu (1) tahap persiapan sampel dan (2) tahap karakterisasi sampel. Kedelai hitam dan beras merah diperoleh dari produk komersil yang tersedia banyak di pasar-pasar tradisional maupun supermarket.

Sampel beras merah dan kedelai hitam masing-masing digerus dengan mortal sampai homogen. Serbuk beras merah dan kedelai hitam dikarakterisasi dengan menggunakan AAS. Parameter yang diukur dengan AAS yaitu kandungan logam berat nikel (ni), khrom $(\mathrm{Cr}), \operatorname{kadmium}(\mathrm{Cd})$ dan timah $(\mathrm{Pb})$.

Serbuk beras merah dan kedelai hitam masing-masing sebanyak $25 \mathrm{~g}$ dibuat film dengan cara melarutkan dalam campuran chitosan dan polivinil alkohol (PVA) 75 g. Dalam 75 g campuran chitosan dan PVA perbandingan chitosan dan PVA yaitu 3:7.

Film yang dihasilkan dikarakterisasi dengan TGA pada atmosfer $\mathrm{O}_{2}$. Prosedurnya seperti tercantum pada Gambar 1. Larutan chitosan, PVA dan beras merah disebut Chipoa-B dan larutan chitosan, PVA dan kedelai hitam disebut Chipoa-K. 


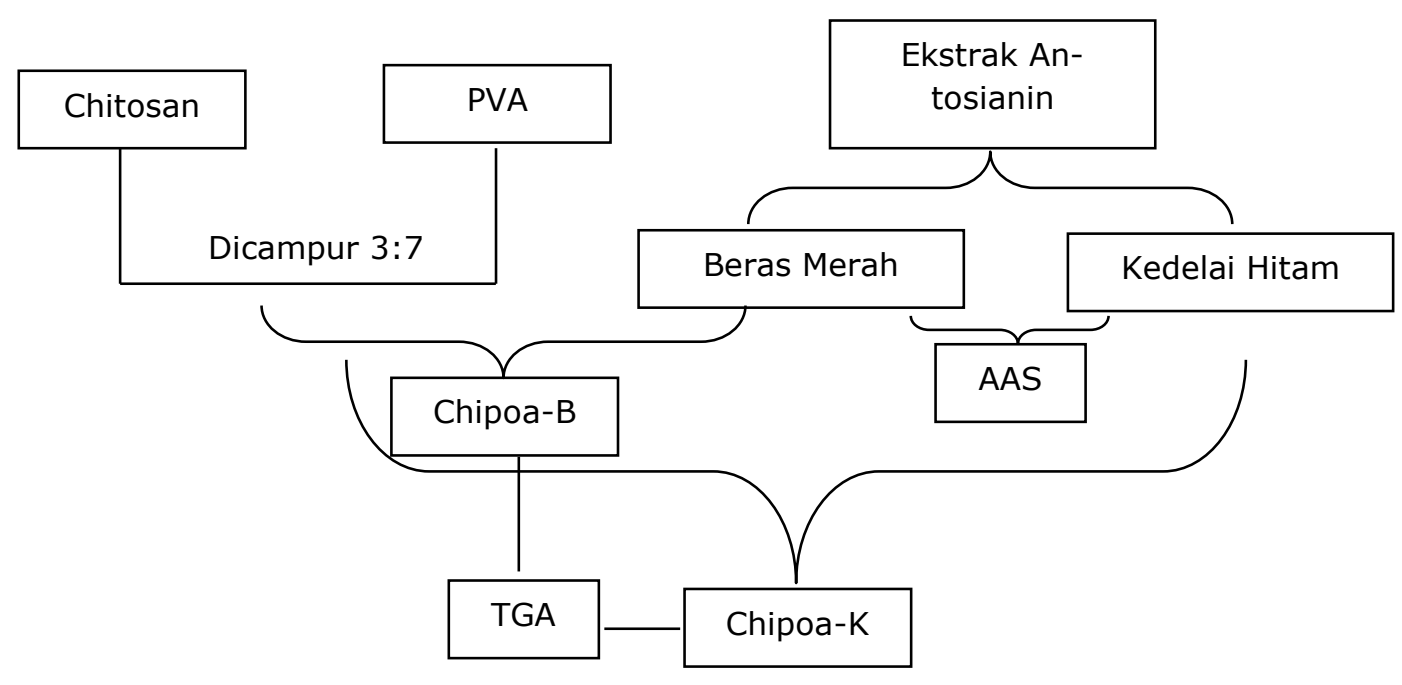

Gambar 1. Diagram alir penelitian.

\section{HASIL DAN PEMBAHASAN}

Hasil pengujian kandungan logam berat dalam serbuk beras merah dan kedelai hitam dengan menggunakan AAS ditunjukkan pada Tabel 1. Tabel 1 menunjukkan bahwa kedua bahan tersebut aman dijadikan ekstrak antosianin sebagai kandidat indikator kualitas makanan atau minuman khususnya minuman susu cair. Baik beras merah maupun kedelai hitam, keduanya aman dari kandungan logam berat. Sehingga kedua jenis ekstrak antosianin dari beras merah dan kedelai hitam dibuat film dan dikarakterisasi dengan TGA, hasilnya seperti ditunjukkan pada Gambar 2 dan Gambar 3

Tabel 1. Kandungan logam berat dalam kedelai hitam dan beras merah.

\begin{tabular}{cccc}
\hline $\begin{array}{c}\mathrm{N} \\
\mathrm{o}\end{array}$ & Parameter & $\begin{array}{c}\text { Kedelai } \\
\text { Hitam }\end{array}$ & $\begin{array}{c}\text { Beras } \\
\text { Merah }\end{array}$ \\
\hline 1. & Nikel $(\mathrm{Ni})$ & $\mathrm{ND}^{*}$ & ND* \\
2. & Khrom $(\mathrm{Cr})$ & $\mathrm{ND}^{*}$ & ND* \\
3. & Kadmium $(\mathrm{Cd})$ & $\mathrm{ND}^{*}$ & $\mathrm{ND}^{*}$ \\
4. & Timah $(\mathrm{Pb})$ & $\mathrm{ND}^{*}$ & $\mathrm{ND}^{*}$ \\
\hline
\end{tabular}

ND*: not defined

Gambar 2 menunjukkan hasil karakterisasi film Chipoa-K dengan TGA, dari gambar terlihat bahwa mulai pada suhu $59,83{ }^{\circ} \mathrm{C}$ film Chipoa-K sudah kehilangan bobot massanya sebanyak $2,5 \mathrm{mg}(10,11$ $\%)$. Penurunan massa berikutnya terjadi pada suhu $199,11{ }^{\circ} \mathrm{C}$ sebesar $9,27 \mathrm{mg}(37,47 \%)$, pada suhu $410,69^{\circ} \mathrm{C}$ sebanyak $6,77 \mathrm{mg}(27,36 \%)$, dan pada suhu $470,51{ }^{\circ} \mathrm{C}$ sebesar $1,32 \mathrm{mg}(5,35 \%)$.

Gambar 3 menunjukkan hasil karakterisasi film Chipoa-B dengan TGA. penurunan massa mulai terjadi pada suhu $39,22{ }^{\circ} \mathrm{C}$ sebanyak $1,67 \mathrm{mg}(8,59$ $\%)$. Penurunan massa berikutnya yaitu terjadi pada suhu $213,72{ }^{\circ} \mathrm{C}$ sebesar 3,68 mg (18,88\%), pada suhu $289,04{ }^{\circ} \mathrm{C}$ sebanyak 3,92 $\mathrm{mg}(20,09 \%)$, dan pada suhu 402,02 ${ }^{\circ} \mathrm{C}$ sebesar 7,67 $\mathrm{mg}(39,33 \%)$.

Jika dibandingkan antara Chipoa-K dengan Chipoa-B, Chipoa-B lebih cepat kehilangan massanya dan pada suhu $402,02{ }^{\circ} \mathrm{C}$ sudah mulai konstan massanya. Sedangkan Chipoa-K massanya mulai konstan pada suhu $470,51{ }^{\circ} \mathrm{C}$. Kondisi ini menandakan bahwa Chipoa-K lebih kuat dibandingkan dengan Chipoa-B. Sehingga ekstrak antosianin yang berasal dari kedelai hitam lebih memiliki kriteria untuk dibuat film dibandingkan dengan ekstrak antosianin yang berasal dari beras merah.

Hasil karakterisasi dengan TGA didukung dengan hasil penelitian sebelumnya terkait dengan kadar antosianin pada kedelai hitam yang dilakukan oleh Astri [14] dan pengukuran kadar antosianin dalam beras merah oleh Sompong [12], telah diperoleh bahwa kadar antosianin dalam kedelai hitam lebih besar dibandingkan dalam beras merah. Hal ini juga yang akan menjadikan film dari kedelai hitam lebih sensitif jika digunakan sebagai pendeteksi atau indikator kualitas minuman susu cair, karena kedelai hitam mempunya jangkauan nilai antosianin yang lebih lebar dibandingkan dengan film yang dibuat dari ekstrak antosianin beras merah. 


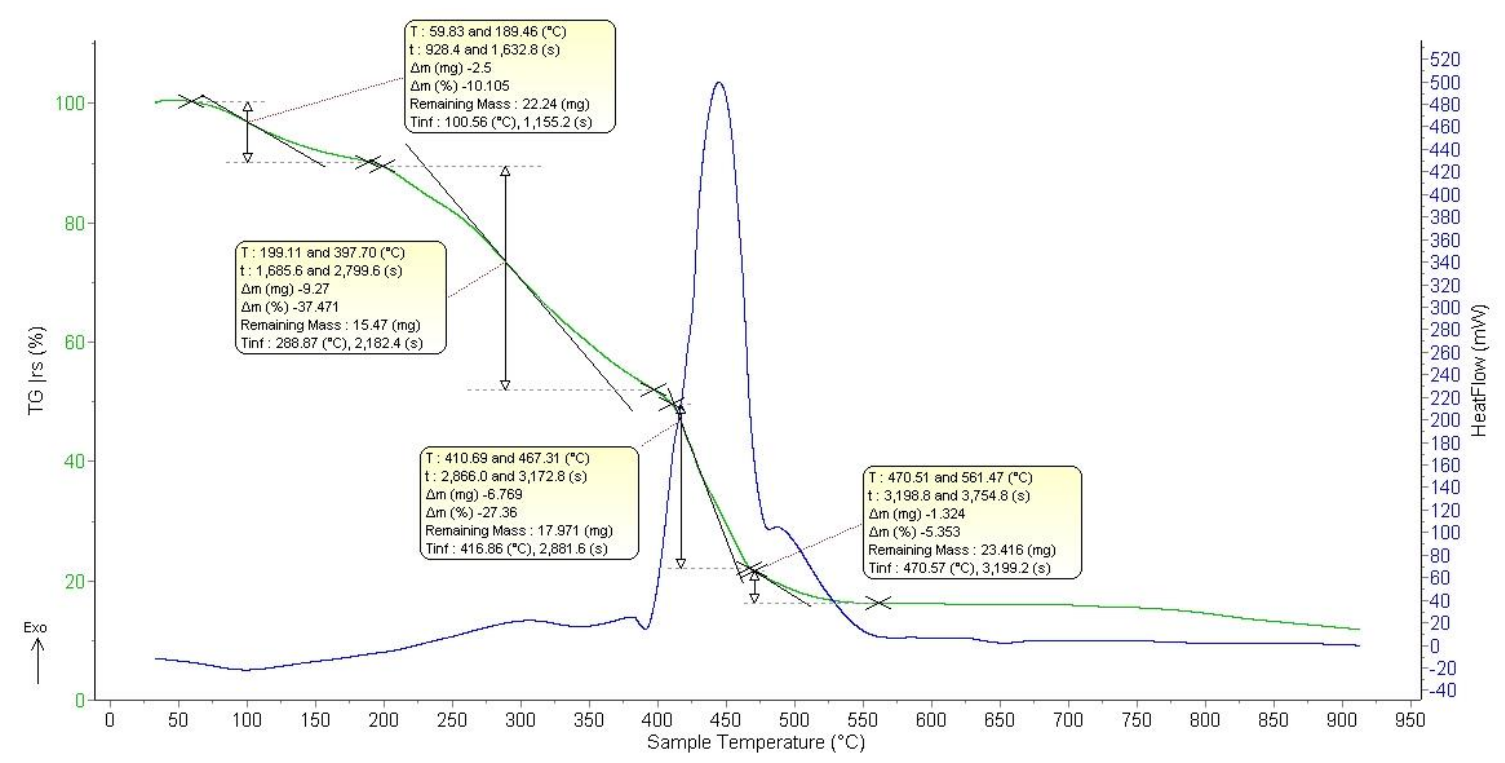

Gambar 2. Kurva TGA dari Chipoa-K

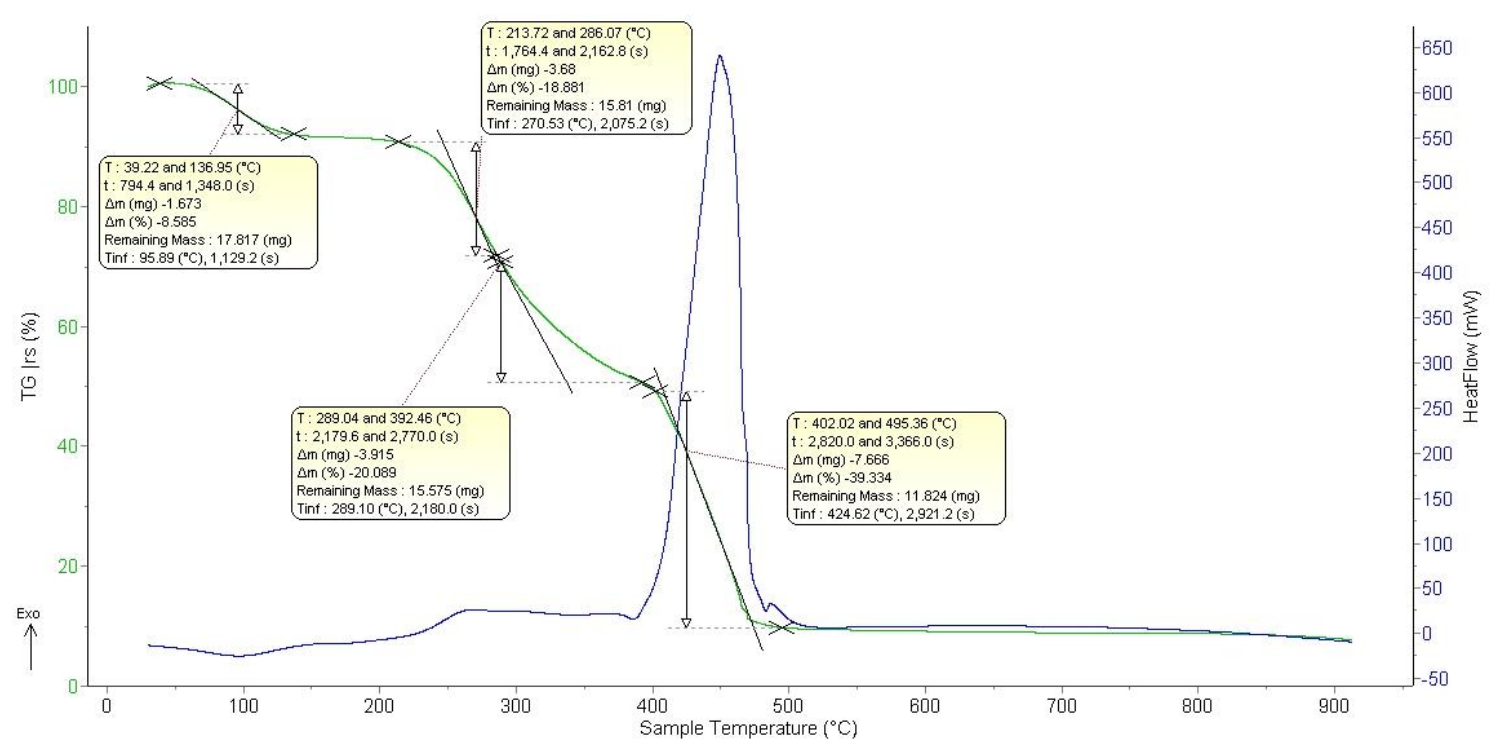

Gambar 3. Kurva TGA dari Chipoa-B

\section{KESIMPULAN}

Berdasarkan hasil karakterisasi dan analisis terhadap beras merah dan kedelai hitam, diperoleh bahwa kedua bahan tersebut aman digunakan sebagai indikator kualitas makanan atau minuman karena tidak mengandung logam berat.

\section{UCAPAN TERIMAKASIH}

Apresiasi dan terima kasih kepada Direktorat Riset dan Pengabdian Masyarakat, DirjenPenguatan Riset dan Pengembangan, Kementerian Riset, Teknologi dan Pendidikan Tinggiyang telah membiayai kegiatan penelitian kompetitif nasional Penelitian Strategi Nasional Institusi Tahun 2018dengan judul: "Karakterisasi dan Analisis Smart Packaging ChiPoA Sebagai Indikator Minuman Susu Layak Konsumsi”.Terima kasih juga kepada Kopertis Wilayah III Jakarta dan Lembaga Penelitian danPengabdian Masyarakat Universitas Indraprasta PGRI yang telah membantu kegiatan penelitian ini melalui Kontrak Penelitian 032/KM/PNT/2018 Tanggal 06 Maret 2018. Dan Surat Perjanjian/Kontrak Penelitian UNINDRA Nomor: 0288/SKP.LT/LPPM/UNINDRA/ III/2018, Tanggal 12 Maret 2018. 


\section{DAFTAR PUSTAKA}

[1] Otles, S., dan Buket, Y. (2008) Intelligent foodpackaging. Logforum 4 (3), 1-9.

[2] Riyanto, B., Maddu, A., Hanedi, Y.W. (2010) Kemasan cerdass pendeteksi kebusukan fillet ikan nila. J. Pengolahan Hasil Peikanan Ind. 129-138.

[3] Hidayat. (2006) Metode Perancangan Percobaan: untuk Ilmu-Ilmu Pertanian, Ilmu-Ilmu Teknik, Biologi. CV. Armico. Bandung.

[4] Saati, E.A. 2002. Identifikasi Dan Uji Kualitas Pigmen Kulit Buah Naga Merah (Hylocareus costaricensis). TROPIKA. 10 (2), Majalah Ilmiah Terakreditasi Fakultas Pertanian, Universitas Muhammadiyah Malang

[5] Santoso U. 2006. Antioksidan. Sekolah Pasca Sarjana Universitas Gadjah Mada. Yogyakarta.

[6] Moss, B.W. 2002. The Chemistry of Food Colour. Di dalam: D.B. MacDougall, Editor. 2002. Colour in Food: Improving Quality. Washington: CRC Press.

[7] Harbome, J.B. (1987) Metode fotokimia. Penuntun cara modern menganalisa tumbuhan. ITB. Bandung (terjemahan).

[8] Ai, M., Dedi, F., Nuri, A., Feri, K. (2014) Karakteristik warna dan aktivitas antioksidan ubi jalar ungu. J. Teknol. dan Industri Pangan. 25 (2), 176-184.

[9] Rajguru, N.R., Burgos, D.R., Gealy, C.H. Sneller, and J. McD. Stewar. (2002) Genetic Diversity of red rice in Arkansas. In Rice research studies. Arkansas Agricultural Experiment Station, Fayetteville, Arkansas 72701. p. 99104.

[10] Rahmat, R. 2010. Stabilisasi Mutu Beras Pecah Kulit Melalui Penerapan Teknologi Penyimpanan Hermetik.

http://www.majalahpangan.com/2010/0

4/stabilisasi-mutu-beras-pecah-kulitmelalui penerapan-teknologipenyimpanan-hermetik/ (23 Oktober 2018).

[11] Yodmanee, S., T.T. Karrila, dan P. Pakdeechanuan. 2011. Physical, Chemical and Antioxidant Properties of Pigmented Rice Grown in Southern Thailand. International Food Research Journal, 18 (3), 901-906.
[12] Sompong, R., S. Siebenhandl-Ehn, G. Linsberger-Martin, dan E. Berghofer. 2011. Physicochemical and antioxidative properties of red and black rice varieties from Thailand, China and Sri Lanka. Elsevier Appl. Sci. Pbl., 124, 132-140.

[13] Aak, K., 1989, Kacang Tanah dan Kedelai, Kanisius, Yogyakarta.

[14] Astrie, M. (2016) Karakteristik sifat fisikokimia, kadar antosianin, dan aktivitas antioksidan susu kedelai hitam (Glycine soja) dengan penambahan ektrak jahe (Zingiber officianale rosc.). [skripsi].

[15] Asih, I.A.R.A. (2009) Isolasi dan identifikasi senyawa isoflavone dari kacang kedelai (Glycine max).J. Kim. 3 (1), 33-40. 